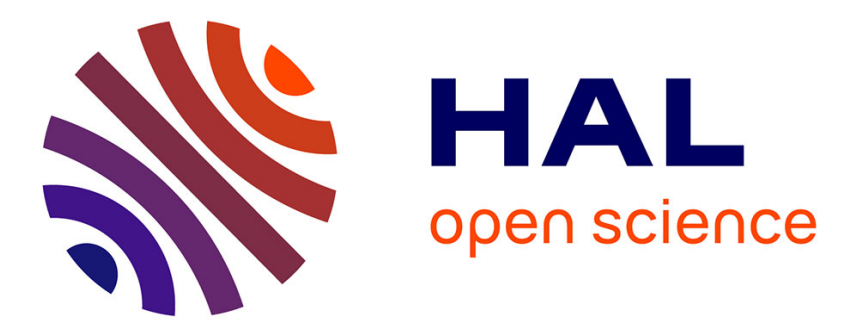

\title{
No HIV-1 molecular evolution on long-term antiretroviral therapy initiated during primary HIV-1 infection
}

Basma Abdi, Thuy Nguyen, Sophie Brouillet, Nathalie Desire, Sophie Sayon, Marc Wirden, Aude Jary, Guillaume Achaz, Lambert Assoumou, Romain

Palich, et al.

\section{To cite this version:}

Basma Abdi, Thuy Nguyen, Sophie Brouillet, Nathalie Desire, Sophie Sayon, et al.. No HIV1 molecular evolution on long-term antiretroviral therapy initiated during primary HIV-1 infection. AIDS. Official journal of the international AIDS Society, 2020, 34 (12), pp.1745-1753. 10.1097/QAD.0000000000002629 . hal-03182806

\section{HAL Id: hal-03182806 https://hal.sorbonne-universite.fr/hal-03182806}

Submitted on 26 Mar 2021

HAL is a multi-disciplinary open access archive for the deposit and dissemination of scientific research documents, whether they are published or not. The documents may come from teaching and research institutions in France or abroad, or from public or private research centers.
L'archive ouverte pluridisciplinaire HAL, est destinée au dépôt et à la diffusion de documents scientifiques de niveau recherche, publiés ou non, émanant des établissements d'enseignement et de recherche français ou étrangers, des laboratoires publics ou privés. 
1 No HIV-1 Molecular Evolution On Long Term Antiretroviral Therapy Initiated During

2 Primary HIV-1 Infection.

3

4 Running head: Viral Diversity In Primary HIV infection

5

6

7

8

9

10

11

12

13

14

15

16

17

18

19 
Authors: Basma ABDI ${ }^{1}$, Thuy NGUYEN ${ }^{1}$, Sophie BROUILLET ${ }^{2}$, Nathalie DESIRE ${ }^{1}$, Sophie SAYON $^{1}$, Marc WIRDEN ${ }^{1}$, Aude JARY ${ }^{1}$, Guillaume ACHAZ ${ }^{2}$, Lambert ASSOUMOU ${ }^{3}$, Romain PALICH ${ }^{4}$, Anne SIMON ${ }^{5}$, Roland TUBIANA ${ }^{4}$, Marc-Antoine VALANTIN ${ }^{4}$, Christine KATLAMA ${ }^{4}$, Vincent CALVEZ ${ }^{1}$, Anne-Geneviève MARCELIN ${ }^{1}$, Cathia SOULIE ${ }^{1}$

${ }^{1}$ Sorbonne Université, INSERM, Institut Pierre Louis d'Epidémiologie et de Santé Publique (IPLESP UMRS 1136), AP-HP, Hôpital Pitié Salpêtrière, Laboratoire de virologie, Paris, France; ${ }^{2}$ Institut de Systématique, Evolution, Biodiversité (ISYEB), Muséum national d'Histoire naturelle, CNRS Sorbonne Université, Paris, France; ${ }^{3}$ Sorbonne Université, INSERM, Institut Pierre Louis d'Epidémiologie et de Santé Publique (IPLESP UMRS 1136), Paris, France; ${ }^{4}$ Sorbonne Université, INSERM, Institut Pierre Louis d'Epidémiologie et de Santé Publique, (IPLESP UMRS 1136), AP-HP, Hôpital Pitié Salpêtrière, Service des Maladies Infectieuses, Paris, France ${ }^{5}$ Sorbonne Université, INSERM, Institut Pierre Louis d'Epidémiologie et de Santé Publique, (IPLESP UMRS 1136), AP-HP, Hôpital Pitié Salpêtrière, Service de Médecine Interne, Paris, France.

Corresponding author : Dr Basma ABDI, Laboratoire de Virologie-CERVI, Hôpital Pitié Salpêtrière 45-83 Bd de l'hôpital 75013 Paris, France. Phone: 331421758 42. Fax: 33142 1774 11.Email: basma.abdi@aphp.fr 


\section{Introduction}

45 Primary-HIV1 (PHI) infection is the initial phase of infection. It represents the time when the virus is first disseminating throughout the body and induces host immune responses [1-3]

The HIV reservoir is established very rapidly during this stage, due to the provirus integrated into the genome of cells that enables the persistence and the establishment of a latent reservoir which remains the major obstacle to eliminate the virus [4].

Several studies have demonstrated that early antiretroviral therapy (ART) initiation can be particularly effective for long term control of HIV-1 replication and it is associated with a faster decay of the latent reservoir, a restriction of its size and an optimal immune restoration [5-7].

Whilst, large clinical trials demonstrated that the benefits of earlier treatment mentioned above were limited at these specific criteria because treatment interruption is usually followed by rapid viral rebound, CD4+ T-cells loss and increased risk of morbidity and mortality [8-11]. ongoing low-level virus replication or by release of viral particles and/or viral genome from infected cells [12]. Effectively, it has been suggested that persistent virus replication at low 
lymphoid tissue sanctuary sites [13]. However, other studies suggest that there is no evidence of HIV replication on ART and the lack of genetic structure of HIV populations during ART argues against ongoing residual replication [13-15].

A better understanding of changes in HIV-1 population genetics with ART is necessary to conclude between these two hypotheses and then for designing and optimizing new eradication strategies. PHI is a particular situation where the low diversity of the transmitted viruses has been described and thus investigating patients who started ART during the earliest stages of their HIV infection provides an opportunity to detect evidence of viral evolution.

We aim to study HIV-1 diversity in patients diagnosed with a primary HIV-1 infection, treated at the time of acute infection and with strict effective long term suppressive ART.

\section{Materials and methods}

We analyzed HIV-1 genetic variation and divergence of viral populations over time in plasma samples (RNA) before ART initiation and in blood cell samples (DNA) during 5 years of viral suppression on ART.

\section{Patients}

We retrospectively studied 20 patients diagnosed during PHI in the Departments of Infectious Diseases and Internal Medicine at Pitié-Salpêtrière Hospital (Paris, France). PHI was defined 
as detectable plasma HIV-RNA and an incomplete HIV-1 Western blot, irrespective of the ELISA result (positive or negative) and p24 antigenaemia (positive or negative).

Patients received antiretroviral therapy very early after infection and were identified with a strict viral suppression (HIV plasma RNA $<20$ copies/mL without any blips) for at least 5 years afterward under ART. Analyses were performed retrospectively on frozen samples of whole blood taken during 5 years of standard follow-up.

\section{Ethical considerations}

This retrospective study was conducted in accordance with Good Clinical Practices and the ethical principles of the Helsinki declaration, and following ANRS standard practices for clinical research. Patients had written consent that the remnant of their samples could be used for research purpose.

\section{Total HIV-DNA quantification}

Cell-associated HIV-1 DNA was quantified by ultrasensitive real-time PCR (Generic HIVDNA assay, Biocentric, Bandol, France) as previously described [16].

\section{HIV-RNA quantification and Ultra-Sensitive Viral Load}

Plasma Viral Load (pVL) was quantified using the Cobas AmpliPrep/CobasTaqMan HIV-1 assay (Roche Diagnostics; lower detection limit of 20 copies/mL). Ultra-sensitive viral load (USVL) in the range of 1-20 copies/mL was indicated qualitatively (presence or absence of detectable signal). 


\section{Ultra-Deep-Sequencing}

103

104

105

106

107

108

109

110

111

112

113

114

115

116

117

118

119

120

121

\section{RNA and DNA extraction, amplification and ultra-deep sequencing}

HIV RNA was extracted from $1 \mathrm{ml}$ of plasma using easyMAG® (bioMérieux Clinical Diagnostics, France) and HIV DNA was extracted from $400 \mathrm{~mL}$ of PBMC using the MagnaPure LC DNA Isolation Kit from Roche according to the manufacturer's instructions.

UDS was performed using Illumina Miseq technology (Illumina, San Diego, CA, USA). We deep sequenced 2 fragments RT1 and RT2 of reverse transcriptase (RT) gene (413pb: 26183031 and 446pb: 2877-3323 relative to HXB2 genome, respectively) and C2V3 region of gp 120 gene (367pb: $7011-7378$ relative to HXB2 genome). Details of primers and PCR procedures used for UDS are described in Supplemental Data.

Three samples were sequenced per patient: one RNA-HIV: plasma at baseline prior ART initiation, two HIV DNA associated with peripheral blood cells under effective ART: first point of $\mathrm{pVL}<20$ copies/mL and 5 years follow-up period. Library construction from purified PCR products (RT1, RT2 and C2V3 amplicons) and 2x300 bp Illumina Miseq paired-end sequencing were performed at the Genotyping and Sequencing Platform, ICM Brain and Spine Institute (Paris, France). Sequences were demultiplexed automatically on the MiSeq platform as part of the data processing steps and two paired fastq files were generated for each sample representing the two paired-end reads.

\section{HIV drug resistance testing by UDS}


122 To identify Drug Resistance Associated Mutations (DRAMs), the sequence reads were analyzed with IDNS ${ }^{\circledR} \odot$ SmartGene 2019 (Advanced sequencing platform) and resistance (Cutoff detection of minority resistant variant of UDS sequences $=2 \%$ ) was interpreted using the latest ANRS resistance algorithm (http://www.hivfrenchresistance.org). Variants present in more than $20 \%$ of the quasispecies were considered to be majority resistant variants and variants present at a proportion between $2 \%$ and $20 \%$ were considered to be minority variants.

\section{Phylogenetic analysis}

We used Geneious research software (version 11) for phylogenetic analysis [17]. The pairedend reads are merged and quality-filtered to remove noise. Alignment is performed using a target-specific profile and a consensus is produced based on a user-selected ambiguity threshold. We used PhyML for maximum-likelihood (ML) phylogenetic reconstruction (Generalized time-reversible model (GTR)). The best subtree pruning and regrafting (SPR) and the nearest neighbor interchange (NNI) heuristic options were selected. The reliability of tree topologies was assessed by bootstrapping using 1000 replications (values $\geq 70 \%$ were considered significant). ML trees were rooted on an outgroup: HIV subtype B consensus (HxB2: K03455; www.hiv.lanl.gov)). Tree figures were viewed and modified with FigTree software (http://tree.bio.ed.ac.uk/software/figtree/).

\section{Diversity analysis}

To look for evidence of ongoing viral replication during ART, HIV populations in samples taken at baseline were compared with the populations present during and after long-term ART in RT and gp120 genes. Phylogenetic trees were constructed for each patient with sequences 
obtained from plasma at baseline prior ART initiation and HIV DNA associated with peripheral blood cells under effective ART (first point of $\mathrm{pVL}<20$ copies/mL and 5 years follow-up period). Population genetic diversity was calculated as average pairwise difference (APD) using MEGAX ( http://www.megasoftware.net ) [18].

Viral evolution was established when temporal structure on ML maximum-likelihood phylogenetic trees and significant change over time of HIV-1 genetic diversity (APD) were observed.

\section{HIV-1 Tropism}

HIV-1 co-receptor usage was predicted by a genotypic method that used the Geno2phenoreceptor rule (https://coreceptor.geno2pheno.org/) and according to ANRS rules (http://www.hivfrenchresistance.org/hiv-tropism.html).

\section{Statistical analysis}

All reported values are medians with interquartile range (IQR) for continuous variables and frequencies and percentages for categorical variables. Changes in cell associated HIV-DNA and CD4 cell count were compared between baseline and month 60 using paired Wilcoxon test and the Mann-Whitney test was for comparison between participants with DRAMs dynamics and those with not. Univariable model was used to identify factors associated with DRAMs: age, sex, transmission group, duration of ART, baseline CD4 and CD8 cell counts, CD4/CD8 ratio, nadir CD4 cell count, time since HIV diagnosis, duration of suppressed viraemia, time to ART initiation, time to undetectable viral load under ART, duration of infection, pre-ART pVL, 
peak of pVL, baseline HIV cell-associated DNA, HIV-1 subtype, CD4 cell count and HIV cellassociated DNA during follow up.

All reported P values are two-tailed, with significance set at 0.05 . Analyses were performed with SPSS statistics version 23.0 for Windows.

\section{Results}

\section{Patients' characteristics at time of PHI}

Twenty patients with strict viral suppression (HIV viral load $<20$ copies/mL without any blips) were included in the study with a median age of 47 years (IQR 34-53). Eighteen (90\%) were male. Nine of the patients (45\%) and 11/20 (55\%) were diagnosed at Fiebig stages III and IV, respectively. Fifteen patients $(75 \%)$ were symptomatic at time of PHI. Time to ART initiation, time to undetectable viral load under ART and duration of infection was in median 5 days (IQR 1-12), 95 days (IQR 40-119) and 6 years (IQR 6-7), respectively. Of the 20 patients, 12 (60\%) were infected with the clade B virus. Main characteristics of patients are summarized in table 1 .

\section{Evolution of immulogical and virological parameters}

Evolution of immunological and virological parameters is presented in figure 1. A median of 10 longitudinal plasma HIV-1 RNA was evaluated per patient (197 samples in total). The median HIV-RNA viral load (VL) at time of PHI was $5.7 \log _{10}$ copies/mL (IQR: 4.94-6.26) and decreased quickly with all patients reaching VL $<20$ copies/mL in a median of 95 days (IQR: 
40 -119) of ART initiation. Ultrasensitive VL (presence of detectable signal between 1-20 copies/mL) was found at least once during the 5 years follow-up in 13/20 patients $(65 \%)$.

The total cell-associated HIV-1 DNA level was assayed for a median of 8 longitudinal blood samples per participant (158 samples in total). The median HIV-1 DNA load at PHI and over 5 years of follow up was $3.24 \log _{10}$ copies/10 6 cells (IQR: 2.72 to 3.49 ) and $1.60 \log _{10}$ copies/10 cells (IQR:1.60), respectively. The analysis revealed a global and significant decrease in total HIV-1 DNA during follow up period $(\mathrm{p}=0.02)$. The total cell-associated HIV-1 DNA load was not detectable ( $<40$ copies $/ 10^{6}$ cells) for $14(70 \%)$ patients at the end of follow up.

\section{Resistance analysis and tropism}

At baseline, DRAMs were detected in RT gene in $3(15 \%)$ patients with 2 majority resistant variants: 2 K103N (98\%) and 1 minority resistant variant Y188H (2\%). Regarding longitudinal dynamics of NRTI and NNRTI DRAMs, DRAMs at baseline were compared with archived DRAMs during follow up period (table 2). New DRAMs were detected in 9 patients (45\%) despite fully sustained suppression of HIV-RNA in plasma with new archived DRAMs in 4/20 (25\%) patients at the first point of $\mathrm{pVL}<20$ copies/mL: patients 4, 5, 16 and 17 . Seven (35\%) individuals had at least 1 emerging DRAM in peripheral blood cells after 5 years of follow up (most of them were detected at less than 10\%): patients 3, 4, 9, 10, 11, 12 and 16 (table 2). Fifty-five percent (5/9) of patients who showed emergence of DRAMs had one residual viremia at least once during follow up. The comparison between the characteristics of patients with new archived DRAMs and those without revealing that only transmission group is associated with the dynamics of archived DRAMs. Effectively, all patients who had variants with new DRAMs were $\operatorname{MSM}(\mathrm{P}=0.02)$. 
Five patients (25\%) had at least one G-to-A mutation resistance associated mutation: patient 4: D67N (9.9\%) and M184I (2.7\%); patient 5: M230I (98.9\%); patient 10: M184I (2.3\%); patient 12: D67N (7.2\%) and patient 16: D67N (4.4\%), M184I (98\%) and M230I (100\%) (table 2).

Fifteen patients (75\%) harbored a CCR5-tropic virus. The genotypic prediction of C2V3 coreceptor tropism did not vary over time in all patients.

\section{Search of potential HIV genetic evolution - Phylogenetic studies}

Phylogenetic analyses were processed in the 20 individuals, in RT and gp120 gene. Analysis showed that in all patients, sequences were intermingled: in each patient, sequences obtained from three different time points were highly homogenous. Tree topologies showed an absence of segregation between sequences in HIV-1 RNA at baseline prior to ART and in cell-associated HIV-DNA during 5 years of ART (figure 2).

The average nucleotide pairwise distance (APD) was estimated between the reads obtained from each time point. In the first sample (in HIV-RNA at baseline prior to ART), the median of APD was 1\% (IQR: 1-1), 1\% (IQR: 1-1) and 2\% (IQR: 1-2) in RT1 fragment, RT2 fragment and gp120 gene respectively. In the second sample (in cell associated HIV-DNA; first time point of plasma $\mathrm{VL}<20$ copies/mL) the median of APD was 1\% (IQR: 1-2), 1\% (IQR: 1-1) and 2\% (IQR: 1-3.75) respectively in RT1 fragment, RT2 fragment and gp120. In the third sample (in cell associated HIV-DNA after 5 years of follow up), the median of APD was 1\% (IQR: 1-2), $1 \%$ (IQR: 1-1) and 2\% (IQR: 1-2) in RT1 fragment, RT2 fragment and gp120 gene respectively. This comparison of the APD in sequences obtained from samples taken at different times showed the absence of arguments of significant viral diversity evolution between primary infection and during the following 5 years. 


\section{Discussion}

237

238

To our knowledge, it is the first study to report quantitative and qualitative analysis by UDS of HIV-1 reservoir in twenty patients diagnosed in the acute phase of infection, treated very early and had strict effective long term suppressive ART (during at least 5 years of follow up). There was a significant decay of HIV-RNA and cell-associated HIV DNA in our study in participants who started ART during the first month of their infection. Phylogenetic analysis showed the absence of genetic divergence and diversity in the RT and gp120 genes over time. However, despite sustained virological control under ART, some minor variations (emergence or disappearance) of DRAMS were evidenced associated or not with the current antiretroviral treatment.

Our results are in line with a number of studies showing the faster decrease of HIV DNA in patients starting ART during acute HIV-1 [19-21] infection . However, some clinical trials evidenced a viral rebound after prolonged virologic suppression with no difference in virological and immunological parameters between immediate and delayed treatment in the vast majority of cases [8-11,22].

In this study, $15 \%$ of NNRTI DRAMs $(2 \mathrm{~K} 103 \mathrm{~N}$ and $1 \mathrm{Y} 188 \mathrm{H})$ were revealed at the time of primary HIV infection. This prevalence is similar to the latest data (2014-2016) from the French cohort of primary infections showing that $18.6 \%$ of patients had DRAMS at baseline with the highest level of resistance to the NNRTI class (13.4\%) [23].

Concerning longitudinal dynamics of minority variants, new DRAMs, not detected at baseline, appeared during follow-up in some patients treated early during the acute phase of HIV-1 infection despite a fully controlled vireamia $<20 \mathrm{cp} / \mathrm{mL}$ and absence of detected residual viremia in $45 \%$ (4/9) of cases. This finding is consistent with the assessments carried out by 
Gantner et al; they used the UDS technique to assess the longitudinal dynamics of viral resistant quasispecies archived in blood and demonstrated that, despite virological control, the diversity of the quasispecies continued to evolve [24]. This could be the result of persistence of a residual viremia below the limit of standard quantification in some patients. Other researchers suggested that the new variants have most probably been selected directly in the blood compartment or other reservoirs because of insufficient drug penetration [24-26]. In addition, some of these new DRAMs in blood cells were G-to-A mutations implicating APOBEC3 editing, a cellular enzyme action and not viral replication [27].

The results of phylogenetic analysis, as well phylogenetic tree and average pairwise distance, suggested the absence of genetic changes in archived HIV-1 DNA in our patients treated during the acute phase of infection with effective ART. Our findings support the majority of the studies reporting the lack of viral evolution during suppressive ART in chronically HIV infected adults, as well as in children treated shortly after birth when viral diversity is low $[14,15,28]$. This absence of sequence divergence is indicative of long-lived cells infected and argues against viral replication being the major source of persistent viremia $[14,15,28-30]$. On another side, Lorenzo et al. reported that anatomical sanctuary sites such as the lymph nodes can allow residual viral replication on ART, contributing to the maintenance of the HIV reservoir [31]. These findings were strongly criticized by Kearney et al. who re-analyzed data and reported limits of data according to the low number of samples, the short time of the survey and absence of evidence of viral evolution using more complex analyses [29]. There are several reasons to explain controversy results such as differences in study populations (children treated shortly after birth, adults with chronic infection, patients diagnosed in acute phase of infection), in sampling (plasma, cell associated HIV-DNA, lymph nodes), in sequencing (Sanger sequencing, Single Genome Sequencing, UDS: 454 Roche and Illumina technology) and in analysis 
(phylogenetic analysis, measure of the APD, test of panmixia and others mathematics methods...) [13-15,28-30,32].

Phylogenetic analysis allowed the comparison of the integrality of sequences which is more informative about viral diversity than the study of few resistance positions in the RT sequence. Then, the impact of rare resistant variants could be diluted and doesn't impact phylogenetic analysis and could explain the apparent discrepancy between the DRAMs variation and the stability in phylogenetic analysis in our study.

\section{Conclusion}

In conclusion, this study is the first to use the UDS technique to assess the longitudinal dynamics of viral populations in plasma prior to ART and in archived blood cells in sustained ART in patients diagnosed with a primary HIV-1 infection and treated very early. Despite a slight variation of minority resistance-associated mutation variants, there was no clear evidence of viral evolution during a prolonged period of time. Our results underlined that ART initiation during PHI is fundamental to positively impact quantitative and qualitative biological parameters related to the HIV-1 reservoir in order to reduce its size and to control the viral diversity in the perspective to design of HIV-1 cure strategies.

\section{ACKNOWLEDGEMENTS}

The Genotyping and Sequencing Platform, ICM Brain and Spine Institute (Paris, France).

\section{TRANSPARENCY DECLARATION}


All other authors: none to declare.

B.A., C.S., A.G.M., V.C. designed the study; R.P., A.S., R.T., M.A.V., C.K provided medical care to the participants and collected clinical data; B.A., T.N., S.S collected biological data and performed experiments; B.A., T.N., N.D., S.B., G.A., L.A., analyzed results; B.A., C.S. wrote the paper; All authors reviewed and accepted the final version of the manuscript.

\section{REFERENCES}

1 Kassutto S, Rosenberg ES. Primary HIV Type 1 Infection. Clin Infect Dis 2004;

2 Volberding P, Demeter L, Bosch RJ, Aga E, Pettinelli C, Hirsch M, et al. Antiretroviral Therapy in Acute and Recent HIV Infection: A Prospective Multicenter Stratified Trial of Intentionally Interrupted Treatment. AIDS (London, England) 2009; 23:1987.

3 Fiebig EW, Wright DJ, Rawal BD, Garrett PE, Schumacher RT, Peddada L, et al. Dynamics of HIV viremia and antibody seroconversion in plasma donors: implications for diagnosis and staging of primary HIV infection. AIDS 2003; HIV-1 Cluster and a Skewed Immune Homeostasis Drive the Early Spread of HIV among Resting CD4+ Cell Subsets within One Month Post-Infection. PLoS One 2013; 8. doi:10.1371/journal.pone.0064219 
5 Strain MC, Little SJ, Daar ES, Havlir DV, Gunthard HF, Lam RY, et al. Effect of treatment, during primary infection, on establishment and clearance of cellular reservoirs of HIV-1. J Infect Dis 2005; 191:1410-1418.

6 Hocqueloux L, Avettand-Fènoël V, Jacquot S, Prazuck T, Legac E, Mélard A, et al. Long-term antiretroviral therapy initiated during primary HIV-1 infection is key to achieving both low HIV reservoirs and normal T cell counts. J Antimicrob Chemother

7 Schmid A, Gianella S, von Wyl V, Metzner KJ, Scherrer AU, Niederöst B, et al. Profound depletion of $\mathrm{HIV}-1$ transcription in patients initiating antiretroviral therapy during acute infection. PLOS ONE 2010; 5:e13310.

8 Hamlyn E, Ewings FM, Porter K, Cooper DA, Tambussi G, Schechter M, et al. Plasma

9 Grijsen ML, Steingrover R, Wit FWNM, Jurriaans S, Verbon A, Brinkman K, et al. No Treatment versus 24 or 60 Weeks of Antiretroviral Treatment during Primary HIV Infection: The Randomized Primo-SHM Trial. PLoS Med 2012; 9.

10 Pantazis N, Touloumi G, Meyer L, Olson A, Costagliola D, Kelleher AD, et al. The impact of transient combination antiretroviral treatment in early HIV infection on viral suppression and immunologic response in later treatment. AIDS 2016; 30:879888. 
11 Fidler S, Olson AD, Bucher HC, Fox J, Thornhill J, Morrison C, et al. Virological Blips and Predictors of Post Treatment Viral Control After Stopping ART Started in Primary HIV Infection. JAIDS Journal of Acquired Immune Deficiency Syndromes 2017; 74:126-133.

12 Chaillon A, Gianella S, Lada SM, Perez-Santiago J, Jordan P, Ignacio C, et al. Size, Composition, and Evolution of HIV DNA Populations during Early Antiretroviral Therapy and Intensification with Maraviroc. J Virol 2018; 92. doi:10.1128/JVI.0158917

13 Lorenzo-Redondo R, Fryer HR, Bedford T, Kim E-Y, Archer J, Pond SLK, et al. Persistent HIV-1 replication maintains the tissue reservoir during therapy. Nature 2016; 530:51-56.

14 van Zyl G, Bale MJ, Kearney MF. HIV evolution and diversity in ART-treated patients. Retrovirology 2018; 15:14.

15 Kearney MF, Spindler J, Shao W, Yu S, Anderson EM, O’Shea A, et al. Lack of Detectable HIV-1 Molecular Evolution during Suppressive Antiretroviral Therapy. PLoS Pathog 2014; 10. doi:10.1371/journal.ppat.1004010

16 Avettand-Fènoël V, Chaix M-L, Blanche S, Burgard M, Floch C, Toure K, et al. LTR real-time PCR for HIV-1 DNA quantitation in blood cells for early diagnosis in infants born to seropositive mothers treated in HAART area (ANRS CO 01). J Med Virol 2009; 81:217-223.

17 Kearse M, Moir R, Wilson A, Stones-Havas S, Cheung M, Sturrock S, et al. Geneious Basic: An integrated and extendable desktop software platform for the organization and analysis of sequence data. Bioinformatics 2012; 28:1647-1649. 
18 Tamura K, Nei M. Estimation of the number of nucleotide substitutions in the control region of mitochondrial DNA in humans and chimpanzees. Mol Biol Evol 1993; 10:512-526.

19 Chéret A, Bacchus-Souffan C, Avettand-Fenoël V, Mélard A, Nembot G, Blanc C, et al. Combined ART started during acute HIV infection protects central memory CD4+ T cells and can induce remission. $J$ Antimicrob Chemother 2015; 70:2108-2120.

20 Chéret A, Durier C, Mélard A, Ploquin M, Heitzmann J, Lécuroux C, et al. Impact of early cART on HIV blood and semen compartments at the time of primary infection. PLoS ONE 2017; 12:e180191.

21 Leite TF, Delatorre E, Côrtes FH, Ferreira ACG, Cardoso SW, Grinsztejn B, et al. Reduction of HIV-1 Reservoir Size and Diversity After 1 Year of cART Among Brazilian Individuals Starting Treatment During Early Stages of Acute Infection. Front Microbiol 2019; 10. doi:10.3389/fmicb.2019.00145

22 Pantazis N, Touloumi G, Vanhems P, Gill J, Bucher HC, Porter K, et al. The effect of antiretroviral treatment of different durations in primary HIV infection. AIDS 2008; 22:2441-2450.

23 Visseaux B, Assoumou L, Mahjoub N, Grude M, Trabaud M-A, Raymond S, et al. Surveillance of HIV-1 primary infections in France from 2014 to 2016: toward stable resistance, but higher diversity, clustering and virulence? J Antimicrob Chemother 2020; 75:183-193.

24 Gantner P, Morand-Joubert L, Sueur C, Raffi F, Fagard C, Lascoux-Combe C, et al. Drug resistance and tropism as markers of the dynamics of HIV-1 DNA quasispecies in 
blood cells of heavily pretreated patients who achieved sustained virological suppression. J Antimicrob Chemother 2016; 71:751-761.

25 Palmer S, Maldarelli F, Wiegand A, Bernstein B, Hanna GJ, Brun SC, et al. Low-level viremia persists for at least 7 years in patients on suppressive antiretroviral therapy. Proc Natl Acad Sci USA 2008; 105:3879-3884.

26 Doyle T, Smith C, Vitiello P, Cambiano V, Johnson M, Owen A, et al. Plasma HIV-1 RNA detection below 50 copies/ml and risk of virologic rebound in patients receiving highly active antiretroviral therapy. Clin Infect Dis 2012; 54:724-732.

27 Fourati S, Lambert-Niclot S, Soulie C, Wirden M, Malet I, Valantin MA, et al. Differential impact of APOBEC3-driven mutagenesis on HIV evolution in diverse anatomical compartments. AIDS 2014; $28: 487-491$.

28 Van Zyl GU, Katusiime MG, Wiegand A, McManus WR, Bale MJ, Halvas EK, et al. No evidence of HIV replication in children on antiretroviral therapy. J Clin Invest 2017; 127:3827-3834.

29 Kearney MF, Wiegand A, Shao W, McManus WR, Bale MJ, Luke B, et al. Ongoing HIV Replication During ART Reconsidered. Open Forum Infect Dis 2017; 4. doi:10.1093/ofid/ofx173

30 Kearney MF, Wiegand A, Shao W, Coffin JM, Mellors JW, Lederman M, et al. Origin of Rebound Plasma HIV Includes Cells with Identical Proviruses That Are Transcriptionally Active before Stopping of Antiretroviral Therapy. J Virol 2016; 90:1369-1376. 
41531 Lorenzo-Redondo R, Fryer HR, Bedford T, Kim E-Y, Archer J, Pond SLK, et al.

416 Persistent HIV-1 replication maintains the tissue reservoir during therapy. Nature $417 \quad 2016 ; \mathbf{5 3 0}: 51-56$.

41832 Achaz G, Palmer S, Kearney M, Maldarelli F, Mellors JW, Coffin JM, et al. A robust 419 measure of HIV-1 population turnover within chronically infected individuals. $\mathrm{Mol}$ $420 \quad$ Biol Evol 2004; 21:1902-1912. 


\begin{tabular}{|c|c|}
\hline Characteristics & Total $=20$ \\
\hline Age (years), median (IQR) & $47(34-53)$ \\
\hline $\begin{array}{l}\text { Sex-n }(\%) \\
\text {-Male } \\
\text {-Female }\end{array}$ & $\begin{array}{l}18(90 \%) \\
2(10 \%)\end{array}$ \\
\hline $\begin{array}{l}\text { Origin- } \mathrm{n}(\%) \\
\text {-Caucasian } \\
\text {-Others }\end{array}$ & $\begin{array}{c}19(95 \%) \\
1(5 \%)\end{array}$ \\
\hline $\begin{array}{l}\text { Transmission group- } \mathrm{n}(\%) \\
\text {-Men who have Sex with Men } \\
\text {-Heterosexual }\end{array}$ & $\begin{array}{l}15(75 \%) \\
5(25 \%)\end{array}$ \\
\hline Symptomatic PHI- n (\%) & $15(75 \%)$ \\
\hline $\begin{array}{l}\text { HLA B57*01-n }(\%) \\
\text { Negative } \\
\text { ND }\end{array}$ & $\begin{array}{l}10(50 \%) \\
10(50 \%)\end{array}$ \\
\hline $\begin{array}{l}\text { Fiebig stage } \\
\text { III } \\
\text { IV }\end{array}$ & $\begin{array}{l}9(45 \%) \\
11(55 \%)\end{array}$ \\
\hline $\begin{array}{l}\text { HIV-1 RNA Zenith }\left(\log _{10} \text { copies/mL), median (IQR) }\right. \\
\text { HIV-1 RNA ( } \log _{10} \text { copies/mL), median (IQR) } \\
\text { HIV DNA ( } \log _{10} \text { copies } / 10^{6} \text { cells), median (IQR) }\end{array}$ & $\begin{array}{l}5.82(4.94-6.26) \\
5.7(4.94-6.26) \\
3.24(2.72-3.49)\end{array}$ \\
\hline $\begin{array}{l}\text { CD4 nadir cell count }\left(\text { cells } / \mathrm{mm}^{3}\right), \text { median }(\mathrm{IQR}) \\
\text { CD4 cell count }\left(\text { cells } / \mathrm{mm}^{3}\right), \text { median (IQR) }\end{array}$ & $\begin{array}{l}417(325-522) \\
483(325-566)\end{array}$ \\
\hline Duration of infection (years), median (IQR) & $6(6-7)$ \\
\hline $\begin{array}{l}\text { Time from diagnosis to ART initiation (days), median (IQR) } \\
\text { Time to undetectable viral load (days), median (IQR) }\end{array}$ & $\begin{array}{l}5(1-12) \\
95(40-119)\end{array}$ \\
\hline $\begin{array}{l}\text { ART regimen } \mathrm{n}(\%) \\
-2 \mathrm{NRTI}+2 \mathrm{PI} \\
-2 \mathrm{NRTI}+1 \text { INI } \\
-2 \mathrm{NRTI}+1 \mathrm{NNRTI} \\
-2 \mathrm{NRTI}+2 \mathrm{PI}+\mathrm{MVC} \\
-2 \mathrm{NRTI}+\mathrm{MVC}\end{array}$ & $\begin{array}{l}8(40 \%) \\
8(40 \%) \\
2(10 \%) \\
1(5 \%) \\
1(5 \%)\end{array}$ \\
\hline
\end{tabular}

Table 1 : Patients' characteristics at the time of primary infection

PHI=primary HIV-1 infection; ND: Not Determined; NRTI=nucleoside reverse transcriptase inhibitor; NNRTI= non-nucleoside reverse transcriptase inhibitor; $\mathrm{PI}=$ protease inhibitor;

MVC=maraviroc; 


\begin{tabular}{|c|c|c|c|c|}
\hline Patient & $\begin{array}{l}\text { Time } \\
\text { point }\end{array}$ & Ongoing ART & $\begin{array}{l}\text { NRTI DRAMs } \\
\text { (\% quasispecies) }\end{array}$ & $\begin{array}{l}\text { NNRTI DRAMs } \\
\text { (\% quasispecies) }\end{array}$ \\
\hline 3 & $\begin{array}{l}\text { RNA } \\
\text { DNA* } \\
\text { DNA** }\end{array}$ & $\begin{array}{l}\text { TDF/FTC/DRV/RTV } \\
\text { TDF/FTC/RPV } \\
\text { TDF/FTC/DTG }\end{array}$ & $\begin{array}{l}\text { M41L (9.1\%), T69S }(13.6 \%), \\
\text { L74V }(6.0 \%)\end{array}$ & $\mathrm{Y} 188 \mathrm{H}(2.0 \%)$ \\
\hline 4 & $\begin{array}{l}\text { RNA } \\
\text { DNA* } \\
\text { DNA** }\end{array}$ & $\begin{array}{l}\text { ABC/3TC/RAL } \\
\text { TDF/FTC/RPV }\end{array}$ & $\begin{array}{l}\operatorname{D67N}(9.9 \%), K 70 R(2.4 \%), \\
\operatorname{M184I}(2,7 \%), \underline{\operatorname{M} 184 \mathrm{~V}} \\
\underline{(4.8 \%)}\end{array}$ & $\begin{array}{l}\operatorname{K103N}(5,5 \%) \\
\mathrm{V} 90 \mathrm{I}(2,2 \%), K 103 N \\
(7,1 \%), \underline{\mathrm{E} 138 \mathrm{~A}}(2,7 \%)\end{array}$ \\
\hline$\underline{5}$ & $\begin{array}{l}\text { RNA } \\
\text { DNA* } \\
\text { DNA** }\end{array}$ & $\begin{array}{l}\text { TDF/FTC/DRV/RTV } \\
\text { TDF/FTC/DRV/RTV }\end{array}$ & M230I (98.9\%) & \\
\hline$\underline{9}$ & $\begin{array}{l}\text { RNA } \\
\text { DNA* } \\
\text { DNA** }\end{array}$ & $\begin{array}{l}\text { TDF/FTC/DRV/RTV } \\
\text { TDF/FTC/RPV }\end{array}$ & $\underline{\mathrm{M} 184 \mathrm{~V}(8.8 \%)}$ & $\underline{Y 188 L}(2 \%)$ \\
\hline$\underline{10}$ & $\begin{array}{l}\text { RNA } \\
\text { DNA* } \\
\text { DNA** }^{* *}\end{array}$ & $\begin{array}{l}\text { TDF/FTC/DRV/RTV } \\
\text { TDF/FTC/RPV }\end{array}$ & $\begin{array}{l}\text { M184I (2.3\%), M184V } \\
(4.5 \%)\end{array}$ & G190V $(2.1 \%)$ \\
\hline 11 & $\begin{array}{l}\text { RNA } \\
\text { DNA* } \\
\text { DNA** }\end{array}$ & $\begin{array}{l}\text { TDF/FTC/MVC } \\
\text { TDF/FTC/RPV } \\
\text { TDF/FTC/DTG } \\
\text { 3TC/DTG } \\
\end{array}$ & & V179I $(10.2 \%), V 179 D(2.3 \%)$ \\
\hline$\underline{12}$ & $\begin{array}{l}\text { RNA } \\
\text { DNA* } \\
\text { DNA** }\end{array}$ & $\begin{array}{l}\text { TDF/FTC/RAL } \\
\text { TDF/FTC/RPV } \\
\text { TAF/FTC/EVG/COB }\end{array}$ & $\operatorname{M4lL}(3.2 \%)$, D67N (7.2\%) & $K 103 N(7.9 \%)$ \\
\hline$\underline{16}$ & $\begin{array}{l}\text { RNA } \\
\text { DNA* } \\
\text { DNA** }\end{array}$ & $\begin{array}{l}\text { TDF/FTC/RAL } \\
\text { TDF/FTC/RPV } \\
\text { 3TC/DTG } \\
\end{array}$ & $\begin{array}{l}\text { D67N (4.4\%), M184I (98.0\%), } \\
\text { M184V (2.0\%) }\end{array}$ & $\begin{array}{l}\text { E138A }(45.4 \%) \\
\text { M230I (100.0\%) }\end{array}$ \\
\hline 17 & $\begin{array}{l}\text { RNA } \\
\text { DNA* } \\
\text { DNA** }\end{array}$ & $\begin{array}{l}\text { TDF/FTC/DRV/RTV/MVC } \\
\text { TDF/FTC/DRV/RTV } \\
\text { TDF/FTC/EFV }\end{array}$ & $\begin{array}{l}\text { M4lL (7.8\%), } \mathrm{T} 69 \mathrm{~N}(3.7 \%), \\
\underline{\mathrm{T} 69 \mathrm{~S}(4.9 \%)}\end{array}$ & K103N $(11.6 \%)$ \\
\hline
\end{tabular}

Table 1 : UDS evolution of archived Drug Resistance Associated Mutations in plasma (RNA) at baseline and cell-associated HIV-1 DNA (DNA) under effective antiretroviral 
Therapy: results in \% (mutation frequency among all reads); NRTI=nucleoside reverse transcriptase inhibitor; NNRTI= non-nucleoside reverse transcriptase inhibitor; 3TC: lamivudine; ABC: abacavir; TDF: tenofovir disoproxil fumarate; FTC: emtricitabine; RPV: rilpivirine; EFV: efavirenz; DRV/RTV: darunavir/ritonavir; RAL: raltegravir; DTG: dolutegravir, EVG: elvitégravir;; MVC, maraviroc; COB:cobicistat DNA*: first point of plasma viral load $<20$ copies/mL, DNA**: 5 years of follow-up period Underlined: mutations associated with prescribed treatment; Italic: mutations not related with prescribed treatment; Bold: G-to-A mutations; Bold and Underlined: patients with at least 1 residual vireamia during follow up. 


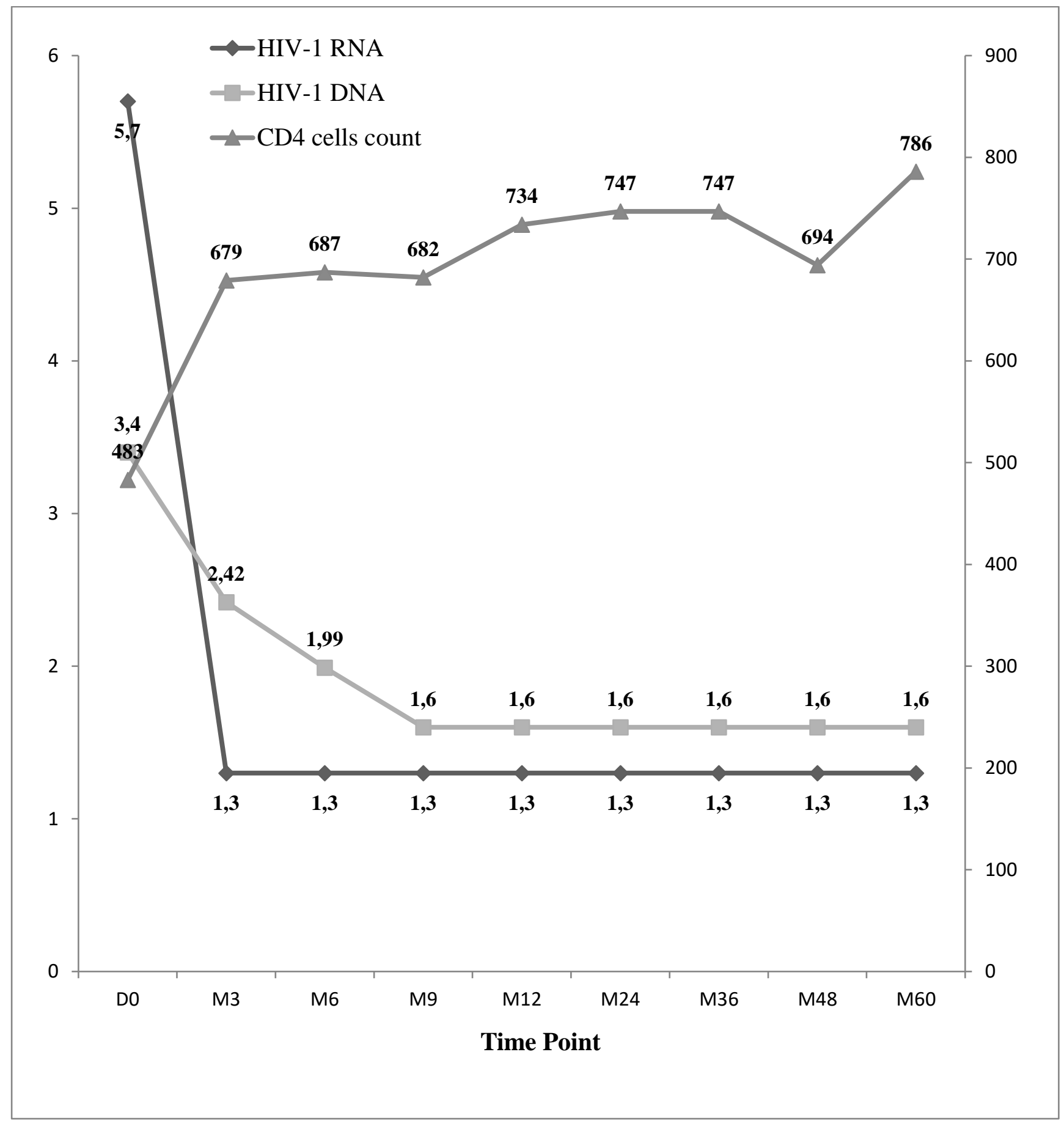

Figure 1: Median of longitudinal plasma HIV-1 RNA, cell associated HIV-1 DNA levels and CD4 cells count in 20 patients: All available samples for 5 years in 20 patients are displayed; D0= Day with confirmed diagnosis of primary HIV-1 infection; M=Month; HIV-1 RNA ( $\log _{10}$ copies/mL); HIV-1 DNA ( $\log _{10}$ copies $/ 10^{6}$ cells); CD4 cells count (cells/mm³) 


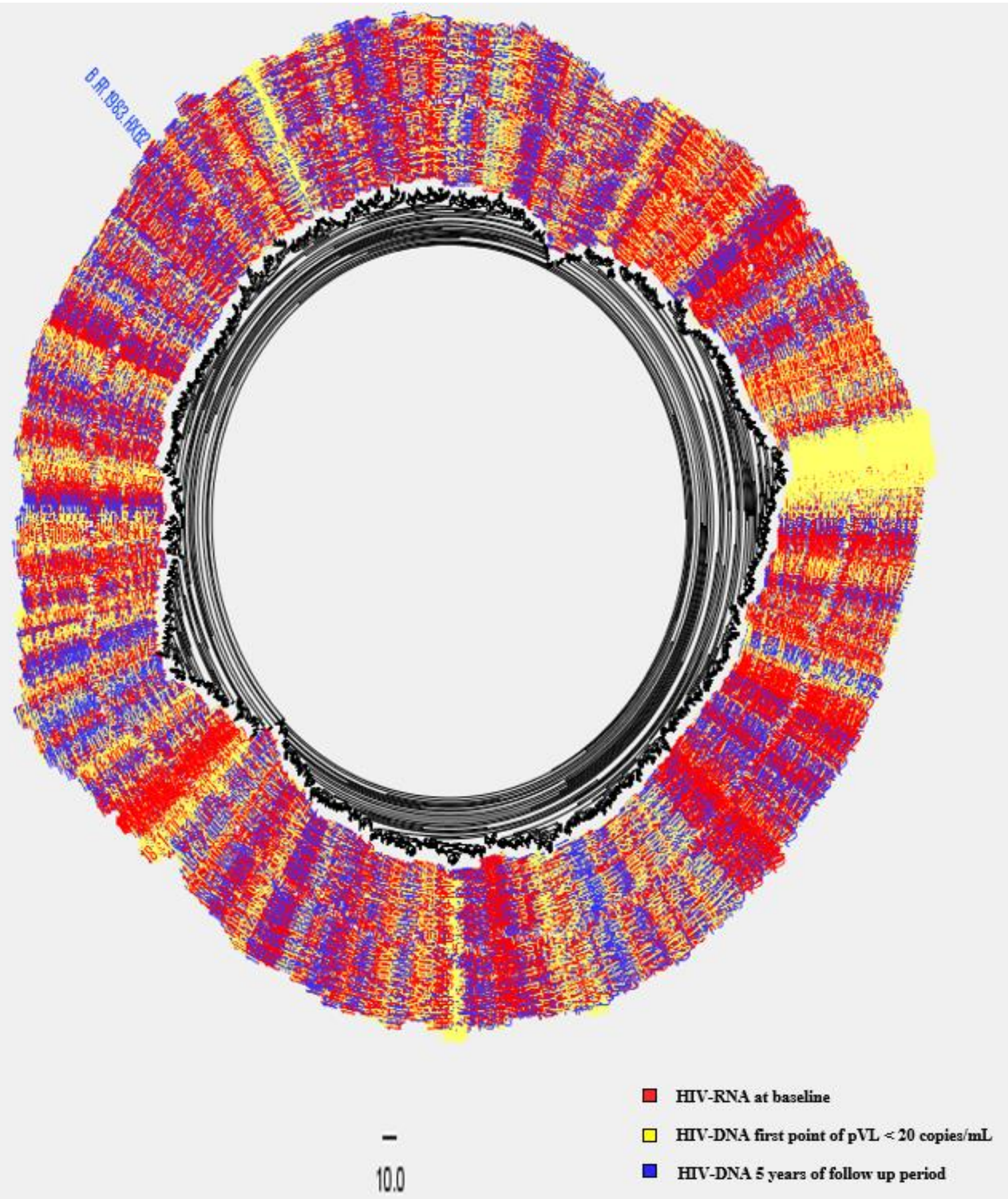

Figure 1 : Example of phylogenetic tree for patient 18 constructed from HIV-RNA at baseline prior ART initiation and HIV-DNA associated with peripheral blood sequences: We used PhyML for maximum-likelihood (ML) phylogenetic reconstruction (Generalised time-reverse model (GTR)); ML tree was rooted on an outgroup: HIV subtype B consensus (HxB2: K03455); phylogenetic tree showing intermingled sequences in RT gene. 


\section{Supplemental Data}

We deep sequenced RT gene into 2 fragments: RT1 (413pb), RT2 (446pb) and gp120 gene (367pb). These genes were amplified using two rounds of PCR amplification.

Details of primers used for amplification are listed in table 1.

PCR1 Forward (for) and PCR1 Reverse (rev) for PCR round one, and PCR 2 for and PCR2 rev for PCR round 2 (nested PCR). To amplify RT1 and RT2 fragments, the following thermocycler parameters were used for PCR1: $50{ }^{\circ} \mathrm{C}$ for 30 minutes $(\mathrm{mn}), 94{ }^{\circ} \mathrm{C}$ for $7 \mathrm{mn}, 94$ ${ }^{\circ} \mathrm{C}$ for 10 seconds (s), $55{ }^{\circ} \mathrm{C}$ for $30 \mathrm{~s}, 68{ }^{\circ} \mathrm{C}$ for $1 \mathrm{mn}, 35$ cycles of steps $3-5$ and $68{ }^{\circ} \mathrm{C}$ for 7 mn. We used a touchdown PCR for round 2 with the following parameters: $98^{\circ} \mathrm{C}$ for $1 \mathrm{mn}$, 3 cycles $\left(98^{\circ} \mathrm{C}\right.$ for $10 \mathrm{~s} ; 66-64{ }^{\circ} \mathrm{C}$ for $30 \mathrm{~s} ; 72^{\circ} \mathrm{C}$ for $\left.15 \mathrm{~s}\right)$, 3 cycles $\left(98^{\circ} \mathrm{C}\right.$ for $10 \mathrm{~s}$; $64-62{ }^{\circ} \mathrm{C}$ for $30 \mathrm{~s} ; 72^{\circ} \mathrm{C}$ for $\left.15 \mathrm{~s}\right), 3$ cycles $\left(98^{\circ} \mathrm{C}\right.$ for $10 \mathrm{~s} ; 62-60{ }^{\circ} \mathrm{C}$ for $30 \mathrm{~s} ; 72^{\circ} \mathrm{C}$ for $\left.15 \mathrm{~s}\right), 30$ cycles $\left(98^{\circ} \mathrm{C}\right.$ for $10 \mathrm{~s} ; 60^{\circ} \mathrm{C}$ for $30 \mathrm{~s} ; 72^{\circ} \mathrm{C}$ for $15 \mathrm{~s}$ ), and $72{ }^{\circ} \mathrm{C}$ for $7 \mathrm{mn}$.

To amplify ENV C2V3 region, the following thermocycler parameters were used for PCR1: $50{ }^{\circ} \mathrm{C}$ for 30 minutes (mn), $94{ }^{\circ} \mathrm{C}$ for $7 \mathrm{mn}, 94{ }^{\circ} \mathrm{C}$ for 10 seconds $(\mathrm{s}), 53{ }^{\circ} \mathrm{C}$ for $30 \mathrm{~s}$,

$68^{\circ} \mathrm{C}$ for $1 \mathrm{mn}, 35$ cycles of steps $3-5$ and $68^{\circ} \mathrm{C}$ for $7 \mathrm{mn}$. Parameters used for PCR 2 were:

$98^{\circ} \mathrm{C}$ for $1 \mathrm{mn}, 98^{\circ} \mathrm{C}$ for $10 \mathrm{~s}, 60^{\circ} \mathrm{C}$ for $30 \mathrm{~s} ; 72^{\circ} \mathrm{C}$ for $15 \mathrm{~s}, 40$ cycles of steps $2-4$ and $72{ }^{\circ} \mathrm{C}$ for $7 \mathrm{mn}$. 


\begin{tabular}{|l|l|}
\hline Primer Name & Primer Sequence (5'-3' orientation) \\
\hline RT1-PCR1-for & TAGTCCTATTGARACTGTACCAGT \\
\hline RT1- PCR1-rev & ATCCTACATACAARTCATCCATG \\
\hline RT1- PCR2-for & ATGGCCATTGACAGAAGAAA \\
\hline RT1- PCR2-rev & TGGAATATTGCTGGTGATCC \\
\hline RT2- PCR1-for & GGGARGTYAATTAGGAATACC \\
\hline RT2- PCR1-rev & AGTCTTTTGATGGGTCATAATA \\
\hline RT2- PCR2-for & GATGTGGGkGATGCATATTT \\
\hline RT2- PCR2-rev & CTGTATGTCATTGACAGTCCAG \\
\hline V3- PCR1-for & CAG TAC AAT GTA CAC ATG G \\
\hline V3- PCR1-rev & ATG GGA GGG GCA TAC ATT G \\
\hline V3- PCR2-for & TTACAGTAGAAAAAT TCC CCT C \\
\hline V3- PCR2-rev & AAT GGC AGTCTA GCAGAA G \\
\hline
\end{tabular}

Table 1 : Primers used for Ultra Deep Sequencing

for=forward; rev=reverse 